\title{
Putting the House in Order
}

BY KATHARINE SMITH DIEHL

SINCE EARLY 1962 the American Libraries Book Procurement Program for India and Pakistan, directed by the Library of Congress and financed through PL 480 funds, has been purchasing, partially processing, and distributing selected books and periodicals to a small number (less than twenty) of American libraries. The publications are in English, Bengali, Hin$\mathrm{di}$, and Urdu; they are representative of the English-speaking public and of the literate and expressive writers in the vernaculars of the entire subcontinent-excepting only the Tamil-Telegu-speaking portion of South India.

Other institutional libraries receive, by individual effort, some of these publications; and all receive a great deal of other material by independent purchase, gift, or exchange. The total linguistic range is certainly not limited to the four languages above mentioned: these just happen to be the current official American interest.

A few angles in this program are disturbing and deserve mention: (1) newsprint, (2) vernaculars, and (3) library problems.

1. Newsprint and book papers are in very short supply in both Pakistan and India. Indigenous raw materials for pulp are more essentially used as housing and fodder than for papermaking. The "ubiquitous bamboo" is converted to housing from Bengal eastward. Some people, including the United States Aid Mission, hoped to use the plant surplus for pulp, only to be disappointed about three years ago when the bamboo flowered andtrue to its nature-died immediately. Several years' delay in the availability of a surplus was the result. Cane from the sugar plantations is animal fodder, but in southeast India another of the inter-
Miss. Diehl is assistant professor at the Graduate School of Library Service, Rutgers.

national assistance projects was concerned with utilizing it. Trees are in short supply, are distant from the paper mills, or are hard to obtain - as those in the Sundarbans which must be harvested from very watery delta lands. Also, trees are used for railroad ties and are even more basic as sources of food: mangos, lichis, walnuts, citrus, almonds, neems, and tamarinds. Furthermore, there has to be natural shade in the tropics!

This pulp shortage results in very expensive books and journals. Their cost is quite out of the economic range of local citizens who would be interested in reading them. The result is a product which is of less sound quality than western books and journals. What seems to be shoddy workmanship is the fault of the national purchasing power-the lack of foreign exchange for such things as paper from Norway - and not of the editor or publisher or author. They want nice paper; they want nice and clear illustrations; they want good bindings-but they cannot have them because credit is more wisely used in the national interest for other things.

In addition to the high cost, published editions are small. It is quite unlikely that, after the first mailing of journals, copies will remain available for more than a few weeks. Editions of one thousand are very common; and in some circles a thousand copies is unrealistically high for a scholarly publication. Except for a very few firms which apparently have sterling or dollar credit which they can tap, books, too, are printed in small 
editions. Government documents get preferred treatment and, judging by many of these titles, the nurture is deserved. The Indian National Bibliography, the numerous JUTE publications from East Pakistan, and most museum publications are nice-even substantial.

As a cumulative result of shortage of raw materials, libraries in the United States interested in securing journals face the loss of occasional copies and inability to secure replacements. Surface mail necessitates a waiting period of up to three months; air mail costs would be exhorbitant and delivery unreliable. Files of journals which are produced on impermanent material are real problems, but if we are serious about wanting them, there is need to be actively interested in finding some solution.

2. The vernaculars and scripts of Asia are almost numberless. Though many persons have enjoyed long years in the subcontinent without knowing their vocabularies, the people who belong there are usually multilingual, and those persons who are literate are usually competent in several scripts. Pakistan has two major languages and one minor: Bengali, in Devanagari character; Urdu, in Persian character; and English, in Roman character. India has fourteen major languages in about five major characters, English in Roman characters, plus the vernaculars and characters of the large immigrant populations from China and Tibet. Unfortunately, India's political divisions were drawn along linguistic boundary lines, state documents are issued in each state's language and characters; and a state language often may not be understood by a person two states removed. UNESCO and USIS have officially encouraged the implementation of the local languages. The British Council, on the other hand, has strongly encouraged English, thus recognizing the urgency of need for a lingua franca.

There is thus no universal language of any South Asian country. That library which receives ten Hindi language journals is getting but slight coverage. Journals in English, too, are excellent and deserve receipt. They are usually written and edited by western-oriented scholars who are in effect bridges between the East and the West.

Library problems with books in $\mathrm{He}$ brew, Russian, Greek are no longer with us. Books in these vernacular alphabets get routine treatment along with books in Roman letters. There is no validity in placing all the books in Hindi character in HINDI (as subject) or Hindi (as classification). One large library, to the chagrin of the librarian-in-charge, has been doing that. Books in the Cyrillic alphabet are not placed in 491.7 any more than all Roman-letter texts are placed in 470 !

One of the several large libraries in Asia, the University of Dacca library, uses letters preliminary to the class number to designate language. This segregates materials without neglecting subject arrangement: e.g., a book by Md. Karim written in Bengali and bearing the title Economics would be numbered B330K; were the book in Urdu it would be numbered U330K.

The basic problem for libraries is the intellectual unreadiness of librarians for these books. We are illiterate in the gravest manner. We do not know the letters of the alphabets; no schedules of the alphabets are available; we have not the slightest notion what the roots of the languages are; we throw off the whole matter with a single word, "exotic," when in fact, they are no more exotic than French, Greek, Russian, or English if one happens to have been born in China, Hungary, or Thailand. It was but a few years ago that the United States State Department began to consider language study essential to its program-a detail the Soviet Union had not neglected.

Actually the PL 480 book procurement program has not placed great onus on the recipient libraries. The project may be here today and gone tomorrow. 
John Charles Finzi, however, is working at it in New Delhi as if it were to last forever. If the institution served by the recipient library exerts pressures, and if the teaching departments use the materials, there will be reasonable hope that the flow of books will outlive the public support, no matter how long that support may continue. But unless teaching departments require the Orientalia, libraries will not process it, and unless libraries process it, teaching departments will not require it. This appears to be a circle; it is not. Libraries are service agencies and have an obligation to make their receipts available to their legal public. A library is morally obligated to secure a person for its staff who can do the necessary work in these languages of Asia. This printed matter deserves the same kind of subject analysis as Roman-letter texts receive.

In addition, the library is under obligation to find some way of filling gaps in serial files. Just to say "Do not claim" is unsatisfactory to the serious reader. Photographic resources are available, and if some kind of union serial ${ }^{1}$ file were to be published, copies could be made either individually or cooperatively.

After people know what is available, indexing is required. Much local housekeeping, local cataloging, and definition of local needs for scholars within each

${ }^{1}$ Efforts are under way at the University of Chicago to prepare a union catalog of serials published since partition in India. Further information can be obtained from the history department, University of Chicago. university or metropolitan community must be completed. Only after there has been an attempt at cataloging, will some of the problems of indexing arise; Indic and Muslim names are one great and fantastic example. Librarians in Asia have not yet settled this; how can those who do not even know the alphabet determine the important part of a person's name!

The library profession, it would seem, must take a bit of responsibility for directing linguistically capable young library school students into this area of special studies. Recently, graduated librarians could be attached, under the Fulbright program as research scholars, to the Universities of Dacca and the Punjab (East and West Pakistan: Bengali and Urdu respectively) and the University of Delhi (India: Hindi) for the express purpose of language study. Each of these universities has teaching programs in librarianship; each has graduates from American accredited library schools on its faculty and staff; each has good library facilities, and good language teachers. It may take a bit of sorting out to find the students who will accept the responsibility seriously and who will determine to learn the language.

The resources are available in this country for language study; American libraries are receiving books in Asian languages. These books require honest and concerted attention which librarians are obligated to give.

\section{Population Parlay for Library Planners}

$$
\text { 1953-54 }
$$

1963

Expenditures for colleges \& universities Number of college \& university students Increase over decade earlier High school students

$\begin{array}{ccc} & \$ 9.3 \text { billion } & \$ 16.5 \text { billion } \\ 2.2 \text { million } & 4.5 \text { million } & 8 \text { million } \\ \text { 6.8 million } & 2.3 \text { million } & 3.5 \text { million } \\ & & 16 \text { million }\end{array}$

1973 (projected)

(Source: Higher Education and National Affairs, September 24.) 